Www.jmscr.igmpublication.org

Impact Factor 5.84

Index Copernicus Value: 71.58

ISSN (e)-2347-176x ISSN (p) 2455-0450

crossref DOI: _https://dx.doi.org/10.18535/jmscr/v5i9.32

Journal Of Medical Science And Clinical Research

\title{
Hairy Cell Leukemia - Variant (HCL-V): A Separate Entity
}

\author{
Authors \\ A.K. Kapoor, Jas Kamal, Akanksha Singh, Pratibha Singh \\ RML Mehrotra Pathology Pvt Ltd., Nirala Nagar, Lucknow, U.P. \\ Corresponding Author \\ Ashok Kumar Kapoor \\ RML Mehrotra Pathology Pvt Ltd, B-171, Nirala Nagar, Lucknow-226020, Uttar Pradesh, INDIA \\ Email:drashokkapoor2016@gmail.com
}

\begin{abstract}
A female, aged 65 years had splenomegaly and atypical lymphocytes in blood smear. Atypical cells had large round nuclei. Flow cytometric (FCM ) findings revealed positivity of atypical cells for CD19, CD103 and CDI1c antigens. She was diagnosed as a case of hairy cell leukemia - variant (HCL-V) subtype. Satisfactory treatment protocol is not available for HCL-V. However, she was advised treatment with monoclonal anti CD 20 antibody (Rituximab $600 \mathrm{mg}$ ivi weekly $\times 4$ doses).

Keywords: Hairy cell leukemia - variant.
\end{abstract}

\section{INTRODUCTION}

HCL-V is a rare B-cell malignancy. It is characterized by severe leucocytosis and splenomegaly ${ }^{1}$. HCL-V cells are usually positive for $\mathrm{CD} 11 \mathrm{c}$, always negative for $\mathrm{CD} 25$ and occasionally positive for CD 103. HCL-V has a central round nucleus, occasional small nucleolus and intensely basophilic cytoplasm. HCL-V cells either give a negative or weak positive reaction to tartaric acid. Binucleate cells are common in HCL-V. Detection of this subtype of HCL is important because leukemic cells do not respond to purine nucleoside analogues and $\alpha$-INF, the agents used in the treatment of HCL-C. Herewith, we describe a case of HCL-V.

\section{CASE REPORT}

A female, aged 65 years complained of weakness, low grade fever and weight loss. Abdominal examination revealed splenomegaly (1+). Superficial lymph nodes were not enlarged. She had leucocytosis; WBC count was 82150 leucocytes $/ \mathrm{mm}^{3}$. DLC revealed presence of atypical lymphocytes (88\%). Atypical cells had large basophilic hairy cytoplasm and large round hyperchromatic nuclei (figure $1 \mathrm{a} \& 1 \mathrm{~b}$ ). The patient had mild anemia ( $\mathrm{Hb} 12.2 \mathrm{gm} / \mathrm{dl}$ ) and mild thrombocytopenia (platelet count 1.41 platelets $/ \mathrm{mm}^{3}$ ). Flow cytometric (FCM) examination with ungated SS/FS revealed a population of large cells (figure 2a). Staining of cells with fluorescein-labelled anti CD19 antibody revealed a strong positivity for CD19 antigen (figure $2 b$ ). FCM analysis using a panel of 2 antibodies (anti CD 103 and anti CD19) revealed negativity for CD 103 antigen on surface membrane of leukemic cells (figure 2c). Later, it was found that surface membrane of atypical cells also contained CD11c 
antigen (figure 2d). On the basis of clinicohematological findings and FCM analysis, the atypical cells were diagnosed as hairy cell leukemia - variant subtype.
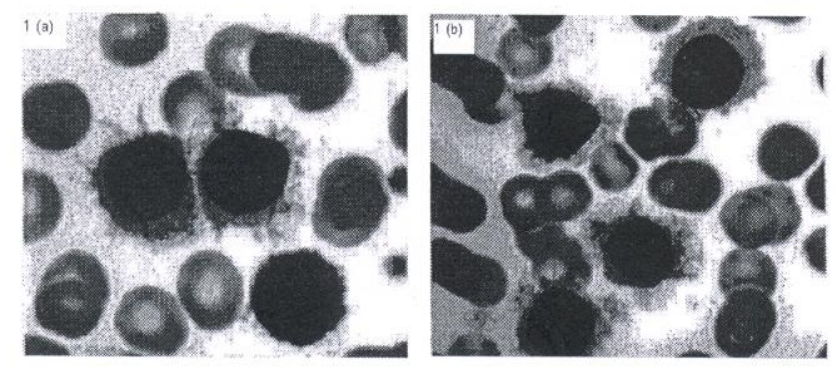

Figure -1 (a) and (b) show morphology of hairy cell leukemia - variant (HCL-V) cells (magnification $\times 1000)$.

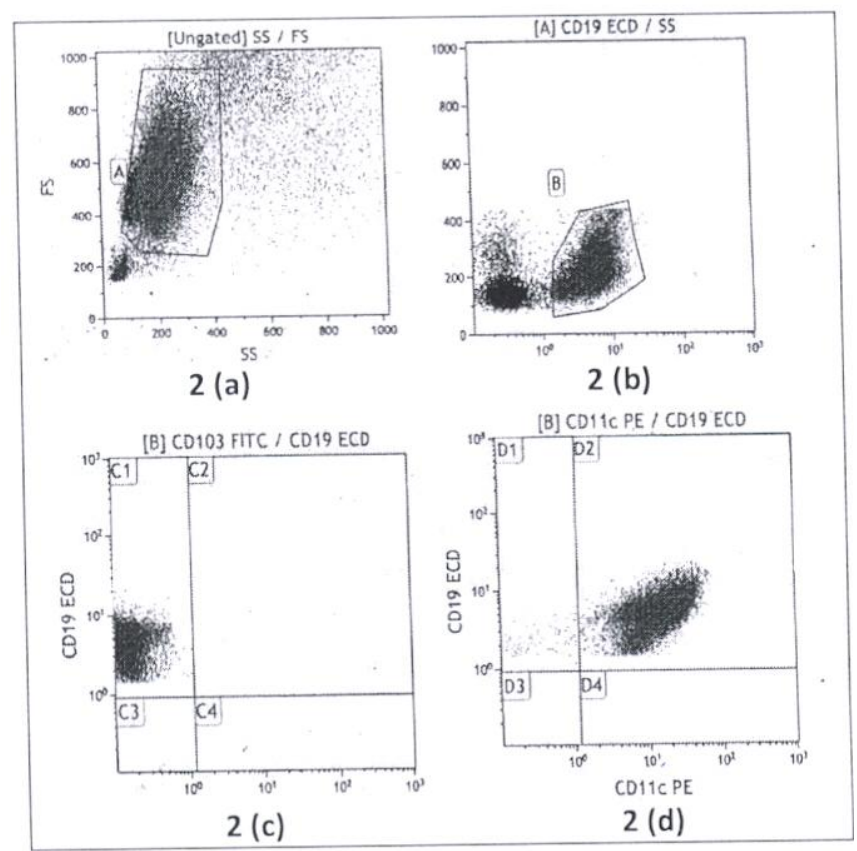

Figure 2 (a) Flow cytometric (FMC) examination with ungated SS/FS revealed a population of large cells. Figure 2 (b) FCM staining of large cells with fluorescein-labelled anti CD 19 showed CD 19 antigen positivity. Figure 2 (c) showed negativity for CD 103 antigen. Figure 2 (d) showed positivity for CD $11 \mathrm{c}$ antigen.

\section{DISCUSSION}

It is a rare case of HCL-V which is being reported. Few cases were reported earlier ${ }^{2}$. HCL in the Chinese population, though rare, is characterized by a higher proportion of HCL-V as compared to classical subtype (HCL-C). In addition, HCL-V may be associated with a second malignancy ${ }^{3}$.
One patient had adenocarcinoma stomach 8 years prior to development of HCL-V. Another patient developed sarcoma neck 18 months after the development of HCL- $\mathrm{V}^{3}$. Moreover, compared to HCL-C, HCL-V had a significantly shorter leukemia-free period. The clinical course of HCL-V may be aggressive as compared to HCLC. Various treatment modalities (Cladribine, Pentostatin and $\alpha$-INF) which are active in HCL-C achieve no response in $\mathrm{HCL}-\mathrm{V}^{4}$. Allogenic marrow transplantation has been tried in a patient with HCL-V and this patient achieved clinical remission for 16 months ${ }^{5}$. Monoclonal anti CD20 (Rituximab) may also be active in $\mathrm{HCL}^{-} \mathrm{V}^{6}$. Matutes et al reported that 13 of 19 HCL-V patients had good partial responses after splenectomy ${ }^{7}$. However, severe deficiency of NK cells has been reported in HCL patients ${ }^{8}$. In addition, pronounced defect in CMI has also been observed ${ }^{9}$.

Common complications associated with HCL-V are bacterial (Escherichia coli-induced urinary infections) and fungal (Aspergillosis) and mycobacterial (pulmonary tuberculosis) infections ${ }^{4,6}$.

Sixteen HCL-V cases were analysed for $B R A F$ including 8 cases expressing HCL-V4-34 immunoglobulin gene rearrangement. BRAF was mutated in all $(100 \%)$ cases. On the contrary, $B R A F$ was mutated only in 42 of $53(79 \%)$ HCL$\mathrm{C}$ patients. Results of this study suggested that HCL-V and IGHV4-34 + HCL cases had a different molecular pathogenesis than HCL-C ${ }^{10}$. In addition, shortened telomers in HCL-V may be associated with decreased survival suggesting if non-chemotherapy options may be useful ${ }^{11}$.

\section{CONCLUSION}

Definite diagnosis of HCL-V is important because this subtype of leukemia does not respond to cladribine and $\alpha$-INF. Instead, the patient with this subtype may require anti CD20 monoclonal antibody (Rituximab) ivi for effective treatment. In addition, splenectomy may have a beneficial effect in HCL-V. 
Financial support and sponsorship: Nil

Conflicts of interest : None

\section{REFERENCES}

1. Wang X, Spielberger R, Huang Q, Hairy cell leukemia variant, a new entity of the WHO 2008. J of Clin Oncol 2011; 29(36): 864-866.

2. Pande P, Yeliskar BR, Mahesh U. A hairy cell leukemia variant - A rare case report. J Clin and Diagnos Res 2013; 7(2); 358360.

3. Kao Hsiao-Wen, Dunn Po,Kuo MingChung, Shih Lee-Yung, Lin Tung-Liang, Wu Jin-Hou, Tang Tzung-Chih, Chang Hung, Wu Hong-Cheng, Hung Yu-Shin. Classical hairy cell leukemia and its variant : A 17-year retrospective survey in Taiwan Chinese. Acta haematologica 2011; 126: 186-193.

4. Gaman AM, Dobrea Camelia-Marioara, Gaman Mihnea Alexandru. A case of hairy cell leukemia variant. Rom J Morphol Embryol 2015, 56(2): 553-556.

5. Busemann C, Schuller F, Kruger W, Kiefer T, Wuppermann M, Androshchuck M, Dolken G. Late extramedullary relapse after allogeneic transplantation in a case of variant hairy cell leukemia. Bone marrow transplant 2010; 45: 1117-1118.

6. Quach H, Januszewicz H, Westerman D. Complete remission of hairy cell leukemia (HCL-V) complicated by red cell aplasia post treatment with rituximab. Haematologica 2005; 90(7) : 72-73.

7. Matutes E, Wotherspoon A, Catavsky D. The variant form of hairy-cell leukaemia. Best pract Res Clin Haematol 2003; 16:4156.

8. Ruco LP, Procopio A, Maccallini V, Calogero A, Uccini S, Annino L, Mandelli F, Baroni CD. Severe deficiency of natural killer activity in the peripheral blood of patients with hairy cell leukemia. Blood 1983; 61:1132-1137.

9. Mackowiak PA, Demian SE, Sutker WL, Murphy FK, Smith JW, Tomsett R, Sheehan WW, Luby JP. Infections of hairy cell leukemia : clinical evidene of a pronounced defect in cell mediated immunity. Am J Med 1980; 68: 718-724.

10. Xi L, Arons E, Navarro W, Calvo KR, Steller-Stevenson M, Raffeld M, Kreitman RJ. Both variant and TGH4-34 expressing hairy cell leukemia lack $B R A F 1 / 600 \mathrm{E}$ mutation 2012; 119: 3330-3332.

11. Arons E, Zhou H, Edelman DC, Gomez A, Steinberg SM, Petersen D, Wong Y, Meltzer PS, Kreitman RJ. Impact of telomere length on survival in classic and variant hairy cell leukemia. Leuk Res 2015; 39 (12) : 1360-1366. 